\title{
Effects of temperature on the feeding behavior of Alabama argillacea (Hübner) (Lepidoptera: Noctuidae) on Bt and non-Bt cotton plants
}

\author{
FRANCISCO S. RAMALHO ${ }^{1}$, JÉSSICA K.S. PACHÚ ${ }^{1}$, ALINE C.S. LIRA ${ }^{1}$, JOSÉ B. MALAQUIAS ${ }^{1}$, \\ BÁRBARA D.S. BRITO ${ }^{1}$, JOSÉ C. ZANUNCIO ${ }^{2}$ and FRANCISCO S. FERNANDES ${ }^{1}$ \\ ${ }^{1}$ Unidade de Controle Biológico, Embrapa Algodão, Av. Osvaldo Cruz, 1143, Centenário, 58428-095 Campina Grande, PB, Brazil \\ ${ }^{2}$ Universidade Federal de Viçosa/UFV, Av. Peter Henry Rolfs, s/n, Campus Universitário, 36570-900 Viçosa, MG, Brazil
}

Manuscript received on July 17, 2015; accepted for publication on March 1, 2016

\begin{abstract}
The host acceptance behavior and environmental factors as temperature affect the feeding behavior of Lepidoptera pests. Thus, they must be considered in studies about the risk potential of resistance evolution. The current study sets the differences in the feeding behavior of neonate Alabama argillacea (Hübner) (Lepidoptera: Noctuidae) larvae exposed to Bt and non-Bt cotton plants, under different temperatures and time gap after hatching. Two cotton cultivars were used: the Bt (DP 404 BG - bollgard) and the nontransformed isoline, DP 4049. We found that the feeding behavior of neonate A. argillacea is significantly different between $\mathrm{Bt}$ and non-Bt cotton. Based on the number of larvae with vegetal tissue in their gut found on the plant and in the organza as well as on the amount of vegetal tissue ingested by the larvae. $A$. argillacea shows feeding preference for non-Bt cotton plants, in comparison to that on the Bt. However, factors such as temperature and exposure time may affect detection capacity and plant abandonment by the larvae and it results in lower ingestion of vegetal tissue. Such results are relevant to handle the resistance of Bt cotton cultivars to A. argillacea and they also enable determining how the cotton seeds mix will be a feasible handling option to hold back resistance evolution in A. argillacea populations on Bt cotton, when it is compared to other refuge strategies. The results can also be useful to determine which refuge distribution of plants is more effective for handling Bt cotton resistance to A. argillacea.
\end{abstract}

Key words: cotton leafworm, feeding behavior, transgenic cotton, blended seed refuge.

\section{INTRODUCTION}

The cotton plant (Gossypium hirsutum Linné) hosts a set of Lepidoptera that defoliate the plant. Whenever they are in high density populations, Lepidoptera cause great loss in crop yield. Cotton leafworm Alabama argillacea (Hübner) (Lepidoptera: Noctuidae) stands out among such

Correspondence to: Francisco de Sousa Ramalho

E-mail: ramalhohvv@globo.com species, due to its destructive capacity (Ramalho et al. 2014). Destruction may occur from the initial phase to the crop maturation in all cotton producer regions in Brazil (Ramalho et al. 2014). Thus, cotton pest control is a limiting factor to the cultivation of this malvaceae, since they represent high production cost due to the countless spraying needed to control insect pests (Ramalho et al. 2014). 
The use of cotton cultivars resistant to cotton leafworm has been suggested as an alternative to chemical control (Schnepf et al. 1999). Bt cotton cultivars are comprised by plants genetically modified by genes of Bacillus thuringiensis var. kurstaki bacteria. These cultivars express protein crystals (Cry) that are lethal if digested by the larvae (Schnepf et al. 1999, Vachon et al. 2012). However, the inserting of a transgene in cotton cultivations may lead to non-expected changes in the plant-insect interaction (Thu Cuc et al. 2008).

Since the commercial liberation of Bt plants in the USA, farmers have adopted such technology in order to get an effective production cost reduction in sustainable agriculture (Klumper and Qaim 2014). However, Lepidoptera monofage as that shown by A. argillacea and the continuous expression of Cry toxins in Bt plants put high selection pressure over target insect populations and, consequently, change the host selection behavior by the larva. Therefore, it favors resistance evolution, since dispersion and/ or the feeding behavior of $A$. argillacea is different between $\mathrm{Bt}$ and non-Bt cotton plants (Ramalho et al. 2014). Spodoptera frugiperda (J.E. Smith) (Lepidoptera: Noctuidae) resistance to the Cry1F toxin found in corn (Zea mays Linné) was observed in Puerto Rico (Storer et al. 2010) as well as Pectinophora gossypiella (Saunders) (Lepidoptera: Gelechiidae) resistance to cotton plants singly expressing Cry1 Ac or Cry1Ac in combination with Cry2Ab2, in India (Dhurua and Gujar 2011). On the other hand, Gassmann et al. (2011), also got to a field finding: a Diabrotica virgifera virgifera LeConte (Coleoptera: Chrysomelidae) strain resistant to $\mathrm{Bt}$ corn plants expressing Cry3Bb1 or Cry34/35Ab1. Thus, the main seed production multinational companies have discussed the possibility of mixing a percentage of non-transgenic seeds in bags with resistant seeds (Zancanaro et al. 2012) as a way to hold back the adaptation evolution of pest insects to the Cry toxin (Agi et al. 2001, Onstad et al. 2011). With regards to refuge in bag "RIB" strategy, a defined percentage of non-Bt plant seeds are mixed with Bt plant ones in each bag. The companies follow the aforementioned procedure so the bags can be sold to producers. However, some implications of this seed mixing technique must be observed, since $A$. argillacea larvae that emerge on Bt plants may do some tasting and get dispersed (Ramalho et al. 2014). Larvae that emerge on nonBt plants may also do tasting, stop feeding and move to a transgenic plant (Gould 2000). Therefore, $A$. argillacea larvae stimulated by $\mathrm{Bt}$ cotton cultivars may migrate to non-Bt cotton plants.

The larval movement of target pest populations between $\mathrm{Bt}$ plants and non-Bt plants is the most important skill in the use of refuge strategies based on seeds mix (Wangila et al. 2012). Lepidoptera neonate pre and post feeding scattering is common when the host has toxins such as those derived from B. thurigiensis (Zalucki et al. 2002). The movement of $A$. argillacea larvae from a $\mathrm{Bt}$ to a non-Bt cotton plant may lead them to ingest sufficient toxin to make this strategy effective against the pest, and therefore, it helps to stop these toxins to emerge in $A$. argillacea populations (Ramalho et al. 2014). With regard to refuge in the bag "RIB" strategy, the biggest "concern" lies on the fact that the larval movement between $\mathrm{Bt}$ and non-Bt plants may booster the resistance evolution in target pest populations (Wangila et al. 2012). According to Wangila et al. (2012), the seeds mix may be able to give refuge to Diatraea saccharalis (Fabricius) (Lepidoptera: Crambidae) and it can be compared with the structured refuge. Besides the host acceptance behavior, environmental factors such as relative humidity and temperature must be considered in studies about the risk potential to resistance evolution (Chen et al. 2012).

High temperatures lead to lower effect on $\mathrm{Bt}$ toxin production (Chen et al. 2005). It does not happen under low temperatures, because, in this case, there is significant increase in the production of this toxin (Chen et al. 2005). Temperature is 
one of the environmental factors that affect the bollworm control efficacy in Bt cotton. Dong and $\mathrm{Li}$ (2007) reported in greenhouse studies that Bt cotton plants significantly lose their insect resistance under high (above $37{ }^{\circ} \mathrm{C}$ ) and low temperatures (below $18{ }^{\circ} \mathrm{C}$ ). According to Chen et al. (2005), high temperatures cause reduction in $\mathrm{Bt}$ protein concentrations during the boll filling stage. The percentage of $A$. argillacea larvae recovered from the cotton plants after $24 \mathrm{~h}$, regardless of the temperature, was significantly higher for the nonBt cotton cultivar than for the Bt cotton cultivar (Ramalho et al. 2014). However, the percentage of neonate $A$. argillacea larvae recovered on cotton plants was lower at 31 and $34{ }^{\circ} \mathrm{C}$ than at 22, 25 and $28^{\circ} \mathrm{C}$, with no differences among the other temperatures. According to Medeiros et al. (2003), A. argillacea larvaereached thermal stress at $33{ }^{\circ} \mathrm{C}$; it was assumed that at $35{ }^{\circ} \mathrm{C}$ and above, the production of enzymes in $A$. argillacea larvae was partially inhibited. In addition to the $A$. argillacea larvae's low acceptance of the host plant, the heat stress, regardless of the cultivars, may stimulate the dispersion behavior of the neonate $A$. argillacea larvae (Ramalho et al. 2014). In general, the percentage of $A$. argillacea larvae found on $\mathrm{Bt}$ cotton plants is less than on non-Bt cotton plants (Ramalho et al. 2014).

Results from previous studies, Ramalho et al. (2014) suggested that further researches were needed to help disclosing neonate A. argillacea larvae feeding behavior when they emerge and find Bt cotton plants as well as how such behavior is affected by temperature throughout time. Thus, the current study aimed to determine differences in neonate $A$. argillacea larvae feeding behavior when they are exposed to Bt and non-Bt cotton plants, under different temperatures and time gaps, after their hatching. We have hypothesized that a1) the percentage of $A$. argillacea larvae found on the plants, with vegetal tissues in their gut is lower in $\mathrm{Bt}$ cotton plants when it is compared with the number of larvae found on non-Bt plants; a2) the percentage of larvae found outside the plants (larvae that have escaped the Bt and non-Bt plants) without food in their gut is lower in Bt cotton plants when it is compared with larvae found in non-Bt. Such difference changes depending on the environmental temperature and time gap they are exposed to the cotton plants. Knowledge generated by the current study will be useful to the development of more effective management programs for $\mathrm{Bt}$ cotton resistance to $A$. argillacea.

\section{MATERIALS AND METHODS}

\section{LOCATION, INSECTS AND COTTON CULTIVARS}

Alabama argillacea rearing as well as the bioassays were performed at Unidade de Controle Biológico da Embrapa Algodão (Biological Control Unit of Embrapa Cotton), Campina Grande, PB, Brazil. $A$. argillacea larvae from the rearing stock were kept in a BOD type acclimatized chamber at $25^{\circ} \mathrm{C}, 70 \pm$ $10 \% \mathrm{RH}$ and $12 \mathrm{~h}$ photophase. Two cotton cultivars were used in the study: a Bt cultivar DP 404 BG (Bollgard) and the other was its non-transformed isoline, cultivar DP 4049. The cultivars were separately grown in plastic pots $(20 \mathrm{~cm}$ diameter and $30 \mathrm{~cm}$ high) and kept in greenhouse under $35 \pm$ $10{ }^{\circ} \mathrm{C}, 70 \pm 10 \% \mathrm{RH}$ and $12 \mathrm{~h}$ photophase.

\section{BIOASSAYS}

Neonate A. argillacea feeding behavior under different temperature and time gap

The experiment was installed in $2 \times 4 \times 5$ factorial system in randomized blocks in which two cotton cultivars (Bt and non-Bt) were used as well as four time gaps. These time gaps were represented by evaluation done at $6,12,18$ and $24 \mathrm{~h}$ after the plant was infested with neonate $A$. argillacea larvae under five temperatures $\left(22,25,28,31\right.$ e $\left.34{ }^{\circ} \mathrm{C}\right)$.

The experimental unit consisted of a cotton plant from the Bt or non-Bt cultivar which had 
reached the eight leaves stage. The plant received 30 recently-hatched larvae $A$. argillacea ( 0 to $24 \mathrm{~h}$ ) that were left on a leaf at the plant's apical region. Next, each plant was dressed with an organza bag and randomly conditioned in a BOD type acclimatized chamber at $22,25,28,31$ and $34{ }^{\circ} \mathrm{C}$, $70 \pm 10 \%$ relative humidity and $12 \mathrm{~h}$ photoperiod.

The bioassay used neonate $A$. argillacea larvae because they present greater mobility and have easier accepted the host plant than larvae in other stages of life (Zalucki et al. 2002). Once a day the plants were moved randomly to minimize the effects of their position within the chamber. After each time gap, the cotton plants and the organza bags were inspected and the larvae were removed using a paintbrush. The larvae were gathered in two categories: found on the plant and in the organza bag (outside the plant). In order to check if the larva had fed, each larva was assembled on microscope slide in Karo ${ }^{\circledR}$ syrup solution diluted in water (Johansen 1940). The larvae were examined through light transmission over their intact bodies to check the presence of vegetable tissue in their gut (Razze et al. 2011). Such fact would be the evidence that the larvae had fed. Subsequently, the material found in the gut of each larva was quantified by means of an ocular micrometer linked to the microscope's ocular with contrast phase. The vegetable tissue identified and quantified in the gut of each larva were: chlorenchyma and tracheary elements (Fig. 1). Chlorenchyma is a specialized parenchyma in charge of photosynthesis and it presents an abundance of visible chloroplasts; whereas the tracheary elements are conducting cells found in the xylem (Evert 2006).

\section{DATA ANALYSES}

The obtained data were subjected to variance analysis (PROC GLM) (SAS Institute 2006) to check if there was cultivar (C), temperature (T) and time gap (t) effects on neonate A. argillacea larvae.
PROC GLM was also used to check the interaction between cultivar and temperature, cultivar and time gap, temperature and time gap; and cultivar, temperature and time gap, with regard to the percentage of larvae that had fed and were found on the plant or on the organza bag (outside the plant). The variance analysis was also used to measure the amount of vegetable tissue (chlorenchyma and/or tracheary elements) (Fig. 1) observed and quantified $\left(\mu \mathrm{m}^{2}\right)$ in the gut of $A$. argillacea larvae in $\mathrm{Bt}$ and non-Bt plants as well as in the organza bag (outside the plant). The comparison of treatment means was performed using the Student-NewmanKeuls test $(P=0.05)$.

\section{RESULTS}

With regards to the percentage of the larvae that had fed and were found on the cotton plant (Table I), it was found that there was no significant interaction among cotton cultivar (C), temperature $(\mathrm{T})$ and the exposure time (Et) A. argillacea larvae were exposed to on cotton plants $\left(\mathrm{F}_{(\mathrm{CxTxEt}) 12,117}=1.15, P\right.$ $=0.3254)$. However, with regards to the percentage of $A$. argillacea larvae that had fed and were found on the cotton plant $\left(\mathrm{F}_{\text {(TxEt) 12,117 }}=2.93, P<0.0014\right)$ (Table I), the interaction between temperature $(\mathrm{T})$ and exposition time (Et) was significant. With respect to the percentage of larvae that had fed and were found on the cotton plants, there were significant differences between cotton cultivars (Bt and non-Bt) as well as the tested temperatures and the time gap in which the larvae were exposed to on cotton plants. Ninety four percent (94\%) of the larvae on the non-Bt cotton plants presented food in their gut, whereas just $70 \%$ of the larvae on Bt cotton plants presented food in their gut (Fig. 2a). The average of vegetable tissues found in the neonate $A$. argillacea larvae was $9.27 \mu \mathrm{m}^{2} /$ larva and $4.67 \mu \mathrm{m}^{2} /$ larva in those on non-Bt and Bt cotton plants (Fig. 2b). The mean percentage of neonate A. argillacea larvae got from cotton plants, under 

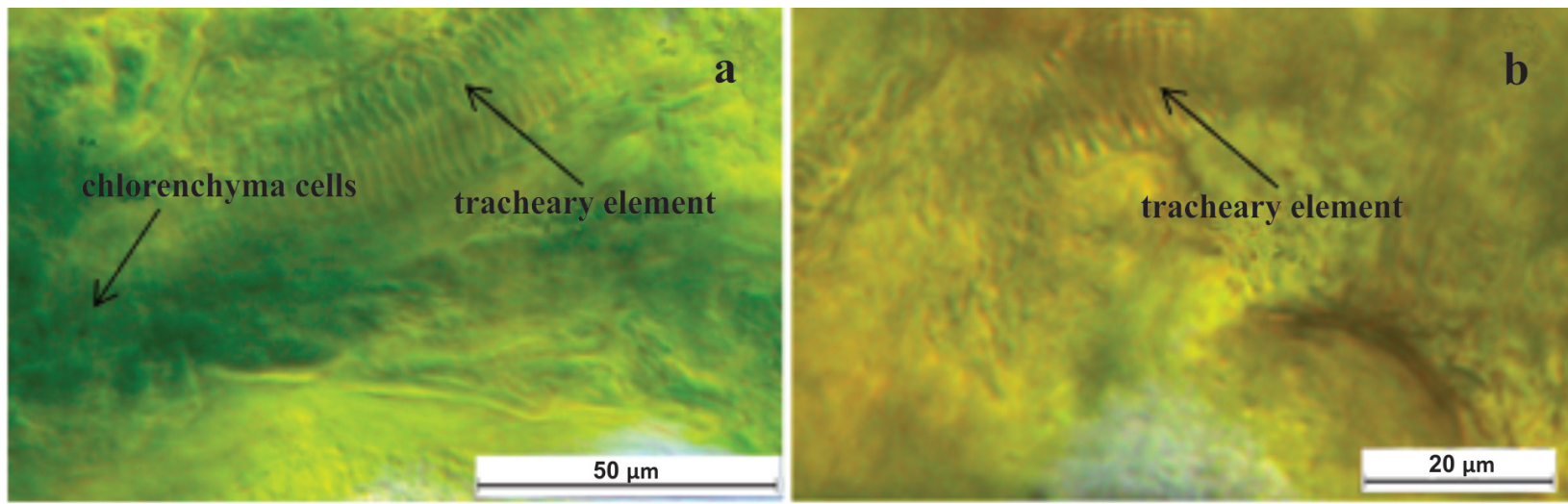

Figure 1 - Plant tissue inside the gut of A. argillacea. a: chlorenchyma cells and tracheary elements in the gut of a neonate larva of $A$. argillacea that had fed on non-Bt cotton for $24 \mathrm{~h}$, and $\mathbf{b}$ : tracheary elements in the gut of a neonate larva of $A$. argillacea that had fed on Bt cotton for $24 \mathrm{~h}$.

the tested temperatures and that had fed, changed depending on the exposure time the larvae were exposed to cotton plants (except for exposure to 28 $\left.{ }^{\circ} \mathrm{C}\right)$ (Table II).

With regards to the percentage of $A$. argillacea larvae that had fed and were found in the organza bag $\left(\mathrm{F}_{(\mathrm{CxTxEt}) 12,117}=32.09, P<0.0001\right)$ (Table I), there was a significant interaction between cotton cultivar (C), temperature (T) and the exposure time (Et) A. argillacea larvae were exposed to cotton plants. However, the effect of cotton cultivars (Bt and non-Bt) on the percentage of larvae that had fed and were found in the organza bags depends on the temperature and the exposure time. It was seen that the percentage of larvae, got in the organza bags, that had fed and came from non-Bt cotton plants at $25^{\circ} \mathrm{C}$ and $31^{\circ} \mathrm{C}$, did not change with the exposure. However, at 22 and $34^{\circ} \mathrm{C}$, the percentage of larvae found in the organza bag and that had eaten was higher when they were exposed for $6 \mathrm{~h}$ on the nonBt cotton plant (Table III). In case of larvae from the Bt cotton plants, the percentage of larva got in the organza bags and that had fed was higher after $24 \mathrm{~h}$ exposure on Bt cotton plants at $31^{\circ} \mathrm{C}$ (Table III). On the other hand, respectively $52 \%$ or $41 \%$ of the lavae found in the organza bags from non$\mathrm{Bt}$ or $\mathrm{Bt}$ cotton plants presented vegetal tissues in their guts (Fig. 2c). The average of vegetable tissue in the guts of neonate $A$. argillacea larvae found in organza bags from non-Bt cotton plants (Fig. 2d) was respectively $4.16 \mu \mathrm{m}^{2} /$ larva and $2.03 \mu \mathrm{m}^{2} /$ larva.

The interaction among cultivar (C), temperature (T) and the exposure time (Et) was significant with regard to the amount of vegetable tissue found in the gut of larvae got on cotton plants $\left(\mathrm{F}_{\text {(CxTxEt) } 12,117}\right.$ $=1.91, P=0.0395)$ (Table IV) or in the organza bags $\left(\mathrm{F}_{(\mathrm{CxTxEt}) 12,117}=32.86, P<0.0001\right)$ (Table IV). It means that the ingestion of vegetable tissue (tissue of cotton plants) by neonate A. argillacea larvae depend on the cotton cultivar (Bt and non-Bt cotton), environmental temperature and exposure time. It was found that after $6 \mathrm{~h}$ of exposition on the cotton plants (Bt and non-Bt), the amount of vegetable tissue in the guts of larvae got on non- $\mathrm{Bt}$ cotton plants was $1.72\left(\right.$ at $22^{\circ} \mathrm{C}$ ), 1.98 (at $25^{\circ} \mathrm{C}$ ), 4.20 (at $28^{\circ} \mathrm{C}$ ), $1.58\left(\right.$ at $31^{\circ} \mathrm{C}$ ) and $1.86\left(\right.$ a $34^{\circ} \mathrm{C}$ ) times higher than that on Bt cotton plants (Table V). A similar behavior was seen in larvae exposed on cotton plants under other exposure times (Table V). More expressive results were recorded for the amount of vegetable tissue in the gut of $A$. argillacea larvae got in the organza bags, i.e., the amount of vegetable tissue in the gut of larvae got 

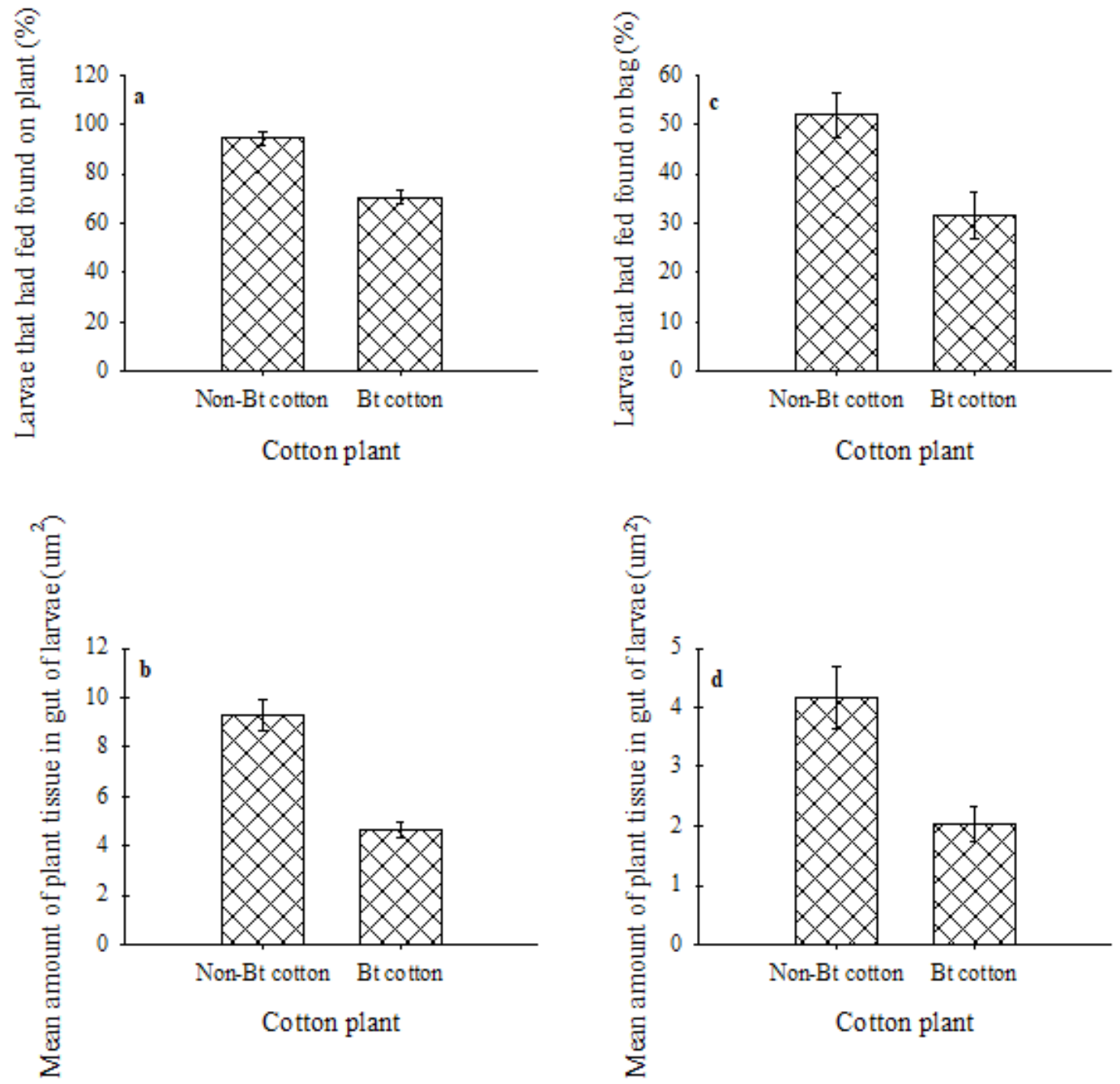

Figure 2 - a: Mean percentage of larvae that had fed that were found on the cotton plant (Bt or non- $\mathrm{Bt})(\mathrm{F}=$ 8.64, $\mathrm{df}=1,117, P=0.0040)$, b: mean plant tissue amount found in the gut of neonate larvae of $A$. argillacea from cotton plant (Bt or non-Bt) $(\mathrm{F}=170.75, \mathrm{df}=1,117, P=0001)$, c: mean percentage of larvae that had fed (Bt or non-Bt) that were found on the bag $(\mathrm{F}=32.49, \mathrm{df}=1,117, P=0.0001)$, and $\mathrm{d}$ : mean plant tissue amount found in the gut of neonate larvae of $A$. argillacea from cotton plant $(\mathrm{Bt}$ or non- $\mathrm{Bt})(\mathrm{F}=123.12, \mathrm{df}=1,117, P$ $=0.0001$ ), and were found on the bag.

in the organza bags, regardless of temperature, was 2.65 (at $6 \mathrm{~h}$ ), 6.56 (at $12 \mathrm{~h}$ ) and 11.91 (at $18 \mathrm{~h}$ ) times higher in larvae got on non-Bt cotton plants than that on Bt cotton plants (Table VI).

\section{DISCUSSION}

Most neonate lepidopterans have a pre-feeding movement phase. This phase may take place within the feed substrate itself or may happen in the long distance dispersion (Berger 1992, Saxena and Onyango 1990) so called Ballooning (Zalucki et al. 2002). Larvae that hatch on Bt plants may do tastings, stop feeding and disperse to other hosts (Razze et al. 2011). The neonate larvae's capacity to detect the presence of toxin in Bt plants is associated to the ingestion of the toxin after the tasting (Yan et al. 2004). However, this pre-feeding behavior of the larvae will depend on contact time and/or the plant's exposure to the larva. This 
TABLE I

Summarized model of the three-way analyses of variance (ANOVA) for the effects of cultivar ${ }^{1}$, temperature ${ }^{2}$ and exposure time $^{3}$ of neonate larvae to Bt cotton or non-Bt cotton on the percentage of neonate larvae of $A$. argillacea that had fed and were found on the plant or bag (Bt or non-Bt near isoline $)^{4}$.

\begin{tabular}{|c|c|c|c|c|}
\hline Source & Models & DF & $F$ ratio & Prob $>$ F \\
\hline \multirow{8}{*}{$\begin{array}{l}\text { Neonate larvae of } A \text {. argillacea that had fed that were } \\
\text { found on the plant }(\%)\end{array}$} & Model & 42 & 4.65 & 0.0001 \\
\hline & Cultivar (C) & 1 & 8.64 & 0.0040 \\
\hline & Temperature $(\mathrm{T})$ & 4 & 18.98 & 0.0001 \\
\hline & Exposure time (Et) & 3 & 14.79 & 0.0001 \\
\hline & $\mathrm{C} \times \mathrm{T}$ & 4 & 1.33 & 0.2643 \\
\hline & $\mathrm{C} \times \mathrm{Et}$ & 3 & 2.26 & 0.0846 \\
\hline & T x Et & 12 & 2.93 & 0.0014 \\
\hline & $\mathrm{C} \times \mathrm{T} \times \mathrm{Et}$ & 12 & 1.15 & 0.3254 \\
\hline \multirow{8}{*}{$\begin{array}{l}\text { Neonate larvae of } A \text {. argillacea that had fed that were } \\
\text { found on the bag }(\%)\end{array}$} & Model & 42 & 39.92 & 0.0001 \\
\hline & Cultivar (C) & 1 & 32.49 & 0.0001 \\
\hline & Temperature $(\mathrm{T})$ & 4 & 97.34 & 0.0001 \\
\hline & Exposure time (Et) & 3 & 10.23 & 0.0001 \\
\hline & $\mathrm{C} \times \mathrm{T}$ & 4 & 14.08 & 0.0001 \\
\hline & $\mathrm{C} \times \mathrm{Et}$ & 3 & 56.78 & 0.0001 \\
\hline & $\mathrm{T} \times \mathrm{Et}$ & 12 & 50.88 & 0.0001 \\
\hline & $\mathrm{C} \times \mathrm{T} \times \mathrm{Et}$ & 12 & 32.09 & 0.0001 \\
\hline
\end{tabular}

${ }^{1}$ Cultivars: Bt cotton and non-Bt near isoline. ${ }^{2}$ Temperature $\left({ }^{\circ} \mathrm{C}\right): 22,25,28,31$, and $34 .{ }^{3}$ Exposure time: $6,12,18$, and 24 h. ${ }^{4}$ Data were square root transformed priori to statistical analyses.

TABLE II

Mean percentage $( \pm \mathrm{SEM})$ of neonate larvae of A. argillacea that had fed that were found on the cotton plants $(\%)\left(\mathrm{F}_{(\mathrm{T}}\right.$ $=2.93, \mathrm{df}=12,117, P<0.0014)$.

\begin{tabular}{ccccc}
\hline $\begin{array}{c}\text { Temperature } \\
\left({ }^{\circ} \mathbf{C}\right)\end{array}$ & \multicolumn{4}{c}{ Exposure time (h) } \\
\cline { 2 - 5 } & $\mathbf{6}$ & $\mathbf{1 2}$ & $\mathbf{1 8}$ & $\mathbf{2 4}$ \\
\hline 22 & $77.68 \pm 0.06 \mathrm{Bb}$ & $81.71 \pm 0.02 \mathrm{Bb}$ & $82.24 \pm 0.03 \mathrm{Bb}$ & $100.00 \pm 0.00 \mathrm{Aa}$ \\
25 & $97.03 \pm 0.01 \mathrm{Ba}$ & $100.00 \pm 0.00 \mathrm{Aa}$ & $100.00 \pm 0.00 \mathrm{Aa}$ & $100.00 \pm 0.00 \mathrm{Aa}$ \\
28 & $100.00 \pm 0.00 \mathrm{Aa}$ & $96.50 \pm 0.03 \mathrm{Aa}$ & $95.83 \pm 0.04 \mathrm{Aab}$ & $100.00 \pm 0.00 \mathrm{Aa}$ \\
31 & $80.55 \pm 0.03 \mathrm{Bb}$ & $81.61 \pm 0.02 \mathrm{Ba}$ & $82.03 \pm 0.05 \mathrm{Bb}$ & $100.00 \pm 0.00 \mathrm{Aa}$ \\
34 & $84.33 \pm 0.04 \mathrm{Bb}$ & $93.75 \pm 0.02 \mathrm{Ab}$ & $95.68 \pm 0.01 \mathrm{Aab}$ & $98.48 \pm 0.01 \mathrm{Aa}$
\end{tabular}

Within rows, means with the same upper case letter do not differ significantly by the Student-Newman-Keuls test $(P=0.05)$; within columns, means with the same lower case letter do not differ significantly by the Student-Newman-Keuls test $(P=0.05)$. Original data. 
TABLE III

Mean percentage ( \pm SEM) of neonate larvae of A. argillacea that had fed that were found on the bag on non-Bt and $\mathrm{Bt}$ plant at different exposure times and temperatures $\left(F_{(C)}\right.$ $=32.09, \mathrm{df}=12,117, P<0.0001)$.

\begin{tabular}{ccccc}
\hline \multirow{2}{*}{ Temperature $\left({ }^{\circ} \mathbf{C}\right)$} & $\mathbf{6}$ & $\mathbf{1 2}$ & $\mathbf{1 8}$ & $\mathbf{2 4}$ \\
\cline { 2 - 5 } & & Non-Bt cotton & \\
22 & $75.00 \pm 14.43 \mathrm{Aa}$ & $0.00 \pm 0.00 \mathrm{Bb}$ & $0.00 \pm 0.00 \mathrm{Bc}$ & $50.00 \pm 10.20 \mathrm{Ab}$ \\
25 & $100.00 \pm 0.00 \mathrm{Ab}$ & $100.00 \pm 0.00 \mathrm{Aa}$ & $100.00 \pm 0.00 \mathrm{Aa}$ & $100.00 \pm 0.00 \mathrm{Aa}$ \\
28 & $37.50 \pm 12.50 \mathrm{Aa}$ & $50.00 \pm 10.20 \mathrm{Ac}$ & $50.00 \pm 12.24 \mathrm{Ab}$ & $0.00 \pm 0.00 \mathrm{Bc}$ \\
31 & $75.00 \pm 5.00 \mathrm{Aa}$ & $75.00 \pm 8.66 \mathrm{Ab}$ & $75.00 \pm 8.66 \mathrm{Aa}$ & $50.00 \pm 20.41 \mathrm{Ab}$ \\
34 & $100.00 \pm 0.00 \mathrm{Aa}$ & $0.00 \pm 0.00 \mathrm{Bd}$ & $0.00 \pm 0.00 \mathrm{Bc}$ & $0.00 \pm 0.00 \mathrm{Bc}$ \\
& & & & \\
\hline & & $\mathbf{B t}$ cotton & & \\
22 & & & & \\
25 & & $0.00 \pm 0.00 \mathrm{Cc}$ & $0.00 \pm 0.00 \mathrm{Cc}$ & $100.00 \pm 0.00 \mathrm{Aa}$ \\
28 & $0.00 \pm 20.41 \mathrm{Bb}$ & $80.00 \pm 8.16 \mathrm{Bb}$ & $100.00 \pm 0.00 \mathrm{Aa}$ & $100.00 \pm 0.00 \mathrm{Aa}$ \\
31 & $0.00 \pm 0.00 \mathrm{Bc}$ & $0.00 \pm 0.00 \mathrm{Bc}$ & $50.00 \pm 0.00 \mathrm{Ab}$ & $50.00 \pm 0.00 \mathrm{Ab}$ \\
34 & $100.00 \pm 0.00 \mathrm{Aa}$ & $100.00 \pm 0.00 \mathrm{Ac}$ & $0.00 \pm 0.00 \mathrm{Bc}$ & $0.00 \pm 0.00 \mathrm{Bc}$ \\
& $0.00 \pm 0.00 \mathrm{Bc}$ & $0.00 \pm 0.00 \mathrm{Ba}$ & $50.00 \pm 17.67 \mathrm{Ab}$ & $50.00 \pm 0.00 \mathrm{Ab}$
\end{tabular}

Within rows, means with the same upper-case letter do not differ significantly by the Student-Newman- Keuls test $(P=0.05)$; within columns, means with the same lower-case letter do not differ significantly by the Student-Newman- Keuls test $(P=0.05)$. Data transformed $\sqrt{\mathrm{x}}$.

behavior was documented in neonate larvae of the Noctuidae species such as Helicoverpa armigera (Hübner) (Lepidoptera: Noctuidae), which also had the capacity and/or the tendency to detect and avoid the Bt cotton plant (Zhang et al. 2004, Men et al. 2005). During choice tests with neonate $H$. armigera larvae on $\mathrm{Bt}$ and non-Bt cotton plants, Zhang et al. (2004) observed higher percentage of $H$. armigera and higher consumption on non- $\mathrm{Bt}$ cotton plants in comparison to the consumption on Bt cotton plants. Similar results were found for Spodoptera exigua (Hübner) (Lepidoptera: Noctuidae) (Berdegué et al. 1996, Stapel et al. 1998), Heliothis virescens (Fabricius) (Lepidoptera: Noctuidae) (Gould and Anderson 1991, Parker and Luttrell 1999), Helicoverpa zea (Hübner) (Lepidoptera: Noctuidae) (Jyoti et al. 1996, Gore et al. 2002, 2005), Ostrinia nubilalis (Hübner) (Lepidoptera: Pyralidae) (Razze et al. 2011), and
Sesamia nonagrioides (Lefebvre) (Lepidoptera: Noctuidae) (López et al. 2013, Jyoti et al. 2013). According to Razze et al. (2011), more than 50\% of neonate $O$. nubilalis larvae left the primary host plant (in which the hatching took place) during the first $48 \mathrm{~h}$ after hatching and dispersed to other plants. However, 21 days after infestation 85 to $94 \%$ of the $O$. nubilalis larvae remained on the corn plants (Ross and Ostlie 1990). A. argillacea larvae showed lesser acceptance to Bt cotton plants than to the non-Bt, especially, in the time gap between 18 and $24 \mathrm{~h}$ (Ramalho et al. 2014).

Results in the current study evidenced that, regardless temperature and exposure time, the percentage of larvae found on plants, with vegetable tissue in their guts was lower than that on $\mathrm{Bt}$ cotton plants when it was compared to that found on nonBt (Fig. 2). Such information about the feeding behavior of $A$. argillacea larvae associated to 
their dispersion behavior when they are exposed to endotoxins produced by $B$. thuringienesis must be seen as an important tool to improve effective strategies in management programs of Bt cotton plants resistance to $A$. argillacea, such as the refuge in the bag "RIB". A. argillacea larvae dispersion is related to host acceptance (Ramalho et al. 2014). It indicates that in a few cases the larvae are more up to leave the Bt cotton plants than the non-Bt. It results in lower food consumption on Bt cotton plants (Ramalho et al. 2014), or they remain in a higher percentage on the plant, but on the other hand, they ingest less vegetable tissue, as it was observed in our study on $A$. argillacea. The occurrence of $A$. Argillacea larvae low mobility among plants within the same agroecosystem and the little ingestion of vegetable tissues are favorable to the maintenance of the refuge strategy effectiveness in Bt plants' plantations. Whenever under "RIB" conditions, the larval movement between plants helps decreasing larval survival of recessive homozygous and the relative increase in the surviving time of heterozygous, due to the higher probability of feeding on Bt plants. Such effect may be reversed within low larval mobility scenarios, thus showing resistance evolution (Glaum et al. 2012).

The physiological response of lepidoptera larvae to toxic or nutritionally inadequate substance found on host plants lead to increase in the movement of larvae looking for better nutritional sources (Cohen et al. 1987). Thus, the dispersion of neonate larvae is important to determine how a refuge will be set in a plantation (Razze and Mason 2012). The feeding behavior of larvae includes the ingestion of vegetable tissue in the tasting phase and it is highly influenced by microclimatic conditions. Therefore, many factors may integrate and generate additive or antagonist effects in host acceptance: food ingestion and subsequent mortality (Zalucki et al. 2002). Temperature differences within greenhouse conditions were enough to result in more consumption, faster growth and stronger larval movement of $D$. saccharalis (Wangila et al. 2012). Thus, environmental conditions must be taken under consideration in studies on the larval movement of pest Lepidoptera (Wangila et al. 2012). The percentage of $A$. argillacea larvae found on $\mathrm{Bt}$ and non-Bt cotton plants was low when they were exposed to temperatures between 31 and 34 ${ }^{\circ} \mathrm{C}$ (Ramalho et al. 2014). The current study shows that the environmental temperature interacts with the cotton cultivar (Bt or non-Bt cultivars) and with the exposure time, during food ingestion, by larvae found on the cotton plant and in the organza bags as well as with the percentage of larvae that had fed and were found in the organza bags. However, the capacity or tendency of $A$. argillacea to detect and avoid Bt cotton plants must be emphasized according to climatic factors such as environmental temperature and exposure time on $\mathrm{Bt}$ cotton plants. The interaction involving temperature, exposure time and cultivar was not significant in terms of the percentage of larvae found on the plant and the amount of vegetal tissue in their guts. However, the interaction temperature $v s$ exposure time affected the percentage of larvae found on the plant and the amount of vegetal tissue in their guts. It was verified that at $28{ }^{\circ} \mathrm{C}$ and exposure time of $6 \mathrm{~h}$ there was high food preference, differently from $22{ }^{\circ} \mathrm{C}$, temperature under which there was less preference. The lower host acceptance percentages were recorded during the 12 and $18 \mathrm{~h}$ period, at 22 and $31^{\circ} \mathrm{C}$ (Table I).

The activity pattern of larvae in different Lepidoptera species is associated to the favorite body temperature. There are modifications in response to changes in environmental conditions (Casey et al. 1988). Behavior changes measured by factors taken under consideration in the current study such as temperature, cultivar and exposure time may help understanding how to mitigate resistance evolution and to optimize the effectiveness of the refuge strategy. The ingestion of vegetable tissue by neonate $A$. argillacea 
TABLE IV

Summarized model of the three-way analyses of variance (ANOVA) for the effects of cultivar ${ }^{1}$ temperature $^{2}$ and exposure time $^{3}$ of neonate larvae to $\mathrm{Bt}$ cotton or non-Bt cotton on plant tissue amount in the gut of neonate larvae of $\boldsymbol{A}$. argillacea that were found on the cotton plant or bag $^{4}$.

\begin{tabular}{|c|c|c|c|c|}
\hline Source & Models & DF & $\mathrm{F}$ ratio & Prob $>$ F \\
\hline \multirow{8}{*}{$\begin{array}{l}\text { Plant tissue amount in the gut of neonate } \\
\text { larvae of } A \text {. argillacea that were found on the } \\
\text { cotton plant }\left(\mu \mathrm{m}^{2}\right)\end{array}$} & Model & 42 & 14.72 & 0.0001 \\
\hline & Cultivar (C) & 1 & 170.75 & 0.0001 \\
\hline & Temperature $(\mathrm{T})$ & 4 & 58.53 & 0.0001 \\
\hline & Exposure time (Et) & 3 & 45.88 & 0.0001 \\
\hline & $\mathrm{C} \times \mathrm{T}$ & 4 & 7.51 & 0.0001 \\
\hline & $\mathrm{C} \times \mathrm{Et}$ & 3 & 0.74 & 0.5329 \\
\hline & Tx Et & 12 & 1.61 & 0.0978 \\
\hline & $\mathrm{C} \times \mathrm{T} \times \mathrm{Et}$ & 12 & 1.91 & 0.0395 \\
\hline \multirow{8}{*}{$\begin{array}{l}\text { Plant tissue amount in the gut of neonate } \\
\text { larvae of } A \text {. argillacea that were found on the } \\
\qquad \text { bag }\left(\mu \mathrm{m}^{2}\right)\end{array}$} & Model & 42 & 51.57 & 0.0001 \\
\hline & Cultivar (C) & 1 & 123.17 & 0.0001 \\
\hline & Temperature $(\mathrm{T})$ & 4 & 103.28 & 0.0001 \\
\hline & Exposure time (Et) & 3 & 61.44 & 0.0001 \\
\hline & $\mathrm{C} \times \mathrm{T}$ & 4 & 38.82 & 0.0001 \\
\hline & $\mathrm{C} \times \mathrm{Et}$ & 3 & 63.31 & 0.0001 \\
\hline & $\mathrm{T} \times \mathrm{Et}$ & 12 & 51.74 & 0.0001 \\
\hline & $\mathrm{C} \times \mathrm{T} \times \mathrm{Et}$ & 12 & 32.86 & 0.0001 \\
\hline
\end{tabular}

${ }^{1}$ Cultivars: Bt cotton and non-Bt near isoline. ${ }^{2}$ Temperature $\left({ }^{\circ} \mathrm{C}\right): 22,25,28,31$, and $34 .{ }^{3}$ Exposure time: $6,12,18$, and 24 h. ${ }^{4}$ Data were square root transformed priori to statistical analyses.

larvae consistently differed between temperatures and cultivars, since in $\mathrm{Bt}$ cotton plants the higher consumption happened at $34{ }^{\circ} \mathrm{C}$. It is different from the non-Bt cotton plants, in which the higher ingestion rate of vegetable tissue by the larvae occurred at $28{ }^{\circ} \mathrm{C}$ (Table II). As some insects are able to selectively distinguish and feed on some parts of the cotton plant with low expressions of B. thuringiensis proteins (Gore et al. 2002), it is possible that most of the ingestion of $\mathrm{Bt}$ cotton plant vegetable tissue happens at $34{ }^{\circ} \mathrm{C}$. It is linked to the synthesis of insecticidal protein, since the expression of Bt toxin may be affected by different factors, not just by the genetic constitution of cotton cultivars but also by environmental conditions (Adamczyk and Sumerford 2001, Zhang et al. 2004, Mahon et al. 2002, Shen et al. 2010), such as light, temperature, water availability and rain fall (Cui and Xia 1999, Xing et al 2001). However, in the current study, the cotton plants were kept under the studied temperatures during the $24 \mathrm{~h}$ evaluation time. Other studies that take under consideration the plant's exposure for a longer period, under different temperatures, might be necessary.

The lower ingestion of vegetal tissue of $\mathrm{Bt}$ and non-Bt cotton plants by neonate $A$. argillacea larvae shows their non-preference for feeding the $\mathrm{Bt}$ in the first $6 \mathrm{~h}$ of exposure, since the amount of vegetable tissue in the guts of larvae got on nonBt cotton plants vary from $1.58\left(31^{\circ} \mathrm{C}\right)$ to 4.20 $\left(25^{\circ} \mathrm{C}\right)$ times higher than that on Bt cotton plants (Table V). Similarly, the amount of vegetable tissue found in the gut of larvae got in the organza bags, regardless of temperature, vary from 2.65 (at 6 
TABLE V

Plant tissue amount $( \pm$ SEM) in the gut of neonate larvae of $A$. argillacea that had fed that were found on the plant Bt and non-Bt on the cotton plant $\left(\mathrm{F}_{(\mathrm{C} \text { versus } \mathrm{T} \text { versus } \mathrm{Et})}=1.91, \mathrm{df}=12,117, P=0.0395\right)$.

\begin{tabular}{|c|c|c|c|c|}
\hline \multirow{2}{*}{$\begin{array}{l}\text { Temperature } \\
\left({ }^{\circ} \mathrm{C}\right)\end{array}$} & \multicolumn{4}{|c|}{ Exposure time (h) } \\
\hline & 6 & 12 & 18 & 24 \\
\hline \multicolumn{5}{|c|}{$\underline{\text { Non-Bt cotton }}$} \\
\hline 22 & $1.88 \pm 0.64 \mathrm{Bc}$ & $4.79 \pm 0.81 \mathrm{Ac}$ & $5.26 \pm 1.20 \mathrm{Ac}$ & $5.37 \pm 0.47 \mathrm{Ad}$ \\
\hline \multicolumn{5}{|l|}{25} \\
\hline & $7.54 \pm 0.39 \mathrm{Bab}$ & $9.07 \pm 0.52 \mathrm{ABab}$ & $10.69 \pm 0.70 \mathrm{Ab}$ & $11.24 \pm 0.77 \mathrm{Abc}$ \\
\hline 28 & $10.34 \pm 2.06 \mathrm{Ba}$ & $11.56 \pm 0.91 \mathrm{Ba}$ & $16.67 \pm 1.72 \mathrm{Ba}$ & $26.28 \pm 3.17 \mathrm{Aa}$ \\
\hline 31 & $4.62 \pm 0.82 \mathrm{Bb}$ & $6.52 \pm 1.09 \mathrm{ABbc}$ & $8.15 \pm 0.67 \mathrm{Ab}$ & $8.92 \pm 0.67 \mathrm{Ac}$ \\
\hline 34 & $5.77 \pm 0.52 \mathrm{Cab}$ & $6.87 \pm 0.40 \mathrm{Cbc}$ & $8.56 \pm 0.62 \mathrm{Bb}$ & $14.34 \pm 0.56 \mathrm{Ab}$ \\
\hline \multicolumn{5}{|c|}{ Bt cotton } \\
\hline 22 & $1.09 \pm 0.38 \mathrm{Ab}$ & $1.73 \pm 1.43 \mathrm{Ab}$ & $2.01 \pm 0.59 \mathrm{Ac}$ & $4.59 \pm 0.29 \mathrm{Ab}$ \\
\hline 25 & $3.80 \pm 0.65 \mathrm{Aa}$ & $4.04 \pm 0.41 \mathrm{Aab}$ & $5.07 \pm 0.49 \mathrm{Ab}$ & $5.47 \pm 0.92 \mathrm{Ab}$ \\
\hline 28 & $2.46 \pm 0.64 \mathrm{Ba}$ & $5.72 \pm 0.65 \mathrm{ABa}$ & $6.95 \pm 1.38 \mathrm{Aab}$ & $8.19 \pm 0.45 \mathrm{Ab}$ \\
\hline 31 & $2.92 \pm 0.50 \mathrm{Ba}$ & $4.05 \pm 0.23 \mathrm{ABab}$ & $4.11 \pm 0.19 \mathrm{ABb}$ & $5.34 \pm 0.70 \mathrm{Ab}$ \\
\hline 34 & $3.10 \pm 0.70 \mathrm{Ba}$ & $4.56 \pm 1.15 \mathrm{ABab}$ & $8.91 \pm 1.47 \mathrm{Aa}$ & $9.22 \pm 2.31 \mathrm{Aa}$ \\
\hline
\end{tabular}

Within rows, means with the same upper-case letter do not differ significantly by the Student-Newman- Keuls test $(P=0.05)$; within columns, means with the same lower-case letter do not differ significantly by the Student-Newman- Keuls test $(P=0.05)$. Original data.

h) to 11.91 (at $18 \mathrm{~h}$ ) times higher in larvae got on non-Bt cotton plants than that on Bt cotton plants. The antibiosis resistance mechanisms and/or the preference for food found in Bt cotton plants must be strictly faced in the time the refuge strategy is chosen (Halcomb et al. 2000). The selection of the host plant according to the food results from the specific complex chemical pattern of each insect species (Beck and Schoonhoven 1980). According to Beck and Schoonhoven (1980), in the presence of such stimuli and during starvation, the insect is induced to feed regardless the presence of the toxin; although the insect has the ability to respond to the toxin. According to Halcomb et al. (2000), there was not effect of the non-preference by the endotoxin found in Bt cotton plants in the 3rd instar $H$. zea and $H$. virescens larvae. The lowest amount of Bt cotton plant vegetable tissue in the gut of $A$. argillacea larvae, in comparison to that found in non-Bt cotton plants, may be attributed to the number of tasting tests done by the larvae exposed to Bt plants. It is common to find a leaf exploration phase in Lepidoptera larvae, the time when they look for more palatable plant tissues. This food selection phase implies the movement of the larvae (Wangila et al. 2012). According to Boiça Junior et al. (2012), the Bt cotton cultivar (NuOpal Bollgard I) expresses resistance to $A$. argillacea by antibiosis mechanisms rather than by food preference. Regarding olygophagous and/or polyphagous, genetic models indicate that cultivars of plants presenting both the antibiosis resistance mechanisms and the non-preference are less up to adapt to target insects when they are compared to 
TABLE VI

Plant tissue amount ( \pm SEM) in the gut of neonate larvae of $A$. argillacea that had fed that were found on the plant Bt and non-Bt on the bag $\left(\mathrm{F}_{(\mathrm{C} \text { versus } \mathrm{T} \text { versus } \mathrm{Et})}=\mathbf{3 2 . 8 6}, \mathrm{df}=12,117, P<0.0001\right)$.

\begin{tabular}{|c|c|c|c|c|}
\hline \multirow{2}{*}{ Temperature $\left({ }^{\circ} \mathrm{C}\right)$} & \multicolumn{4}{|c|}{ Exposure time (h) } \\
\hline & 6 & 12 & 18 & 24 \\
\hline \multicolumn{5}{|c|}{$\underline{\text { Non-Bt cotton }}$} \\
\hline 22 & $1.06 \pm 0.29 \mathrm{Bc}$ & $0.00 \pm 0.00 \mathrm{Cc}$ & $0.00 \pm 0.00 \mathrm{Cc}$ & $5.04 \pm 0.20 \mathrm{Ad}$ \\
\hline 25 & $6.39 \pm 0.05 \mathrm{Ba}$ & $8.43 \pm 0.69 \mathrm{Aa}$ & $9.23 \pm 0.53 \mathrm{Ab}$ & $11.00 \pm 0.00 \mathrm{Acb}$ \\
\hline 28 & $4.00 \pm 0.91 \mathrm{Ba}$ & $4.50 \pm 1.40 \mathrm{Bb}$ & $14.12 \pm 1.65 \mathrm{Aa}$ & $0.00 \pm 0.00 \mathrm{~B} \mathrm{Ca}$ \\
\hline 31 & $0.00 \pm 0.00 \mathrm{Cc}$ & $1.51 \pm 0.38 \mathrm{Bc}$ & $6.15 \pm 0.42 \mathrm{Ab}$ & $6.34 \pm 0.40 \mathrm{Ac}$ \\
\hline 34 & $2.07 \pm 0.01 \mathrm{Bb}$ & $7.53 \pm 0.04 \mathrm{Aa}$ & $0.00 \pm 0.00 \mathrm{Cc}$ & $0.00 \pm 0.00 \mathrm{Cb}$ \\
\hline \multicolumn{5}{|c|}{ Bt cotton } \\
\hline 22 & $3.60 \pm 1.84 \mathrm{ABa}$ & $0.00 \pm 0.00 \mathrm{Bb}$ & $0.00 \pm 0.00 \mathrm{Bb}$ & $6.88 \pm 3.03 \mathrm{Aa}$ \\
\hline 25 & $0.00 \pm 0.00 \mathrm{Cb}$ & $1.10 \pm 0.05 \mathrm{Bab}$ & $4.56 \pm 1.23 \mathrm{Aa}$ & $5.07 \pm 0.58 \mathrm{Aa}$ \\
\hline 28 & $0.00 \pm 0.00 \mathrm{Bb}$ & $0.00 \pm 0.00 \mathrm{Bb}$ & $3.65 \pm 0.36 \mathrm{Aa}$ & $5.56 \pm 1.62 \mathrm{Aa}$ \\
\hline 31 & $1.50 \pm 0.38 \mathrm{Ab}$ & $2.24 \pm 1.13 \mathrm{Aa}$ & $3.20 \pm 0.00 \mathrm{Aa}$ & $3.30 \pm 0.05 \mathrm{Ab}$ \\
\hline 34 & $0.00 \pm 0.00 \mathrm{Bb}$ & $0.00 \pm 0.00 \mathrm{Bb}$ & $0.50 \pm 0.28 \mathrm{Bb}$ & $1.95 \pm 0.57 \mathrm{Ac}$ \\
\hline
\end{tabular}

Within rows, means with the same upper-case letter do not differ significantly by the Student-Newman- Keuls test $(P=0.05)$; within columns, means with the same lower-case letter do not differ significantly by the Student-Newman- Keuls test $(P=0.05)$. Original data.

events with antibiosis (Gould 1984). The evolution of the behavioral resistance may happen if the larvae are able to feed on Bt plants and to develop on the non-Bt ones (Goldstein et al. 2010). There is strong selection stress in A. argillacea continuous expression of the toxin in $\mathrm{Bt}$ cotton plants due to their monophagous feeding behavior. The plantplant dispersion may lead to the ingestion of insufficient amounts of the toxin, to the probability of increased survival of heterozygous and it may also potentially speed up the resistance evolution. Similar results were reported by Goldstein et al. (2010), who stated that $O$. nubilalis presents the ability to detect the endotoxin in Bt corn plants when they are exposed for $24 \mathrm{~h}$. According to Goldstein et al. (2010), the potential of $O$. nubilalis larvae with vegetable tissue in their guts from $\mathrm{Bt}$ corn was higher than that found in insects that have dispersed on non-Bt corn. However, the amount of vegetable tissue in Bt plants was lower when it was compared with that quantified in larvae kept on non-Bt corn (Razze et al. 2011).

Besides the classic feeding preference, other factors may be involved with the lowest percentage of $A$. argillacea larvae on $\mathrm{Bt}$ cotton plants such as larval intoxication, food reduction, inability of the larvae and mortality. According to Halcomb et al. (2000), larvae from the 3rd instar of $H$. zea and $H$. virescens move around cotton plants and indiscriminately feed on $\mathrm{Bt}$ and non-Bt cotton. Some behavioral effects of the interaction between larvae and the Bt cotton plants may be the result of $\delta$-endotoxin after it is ingested by the larvae (Halcomb et al. 2000). On the other hand, the resistance evolution is faster when the larvae move and indiscriminately feed just on Bt or just on non-Bt plants when it is compared with larvae that remain sedentary or that separate Bt plants from the non-Bt ones (Heuberger et al. 2011). In comparison to the structured refuge, the seed mix may increase 
mortality among susceptible insects, if the larva randomly moves around (Mallet and Porter 1992). As per such scenario, the movement/migration of susceptible $A$. argillacea larvae from non-Bt cotton plants to $\mathrm{Bt}$ ones, in RIB, may cause higher mortality among susceptible insects than among that in structured refuge. Consequently, it may result in lower population of $A$. argillacea in the refuge; although the effect of the larval movement on the resistance evolution may change according to the size of the refuge and the prevalence of the resistance (Heuberger et al. 2011). Together, the genic flow mediated by the seeds and the pollen transportation has important effect on the resistance evolution. The indiscriminate movement of $A$. argillacea larvae among cotton plants may consistently increase the association between genic flow and resistance if compared with the behavior of sedentary larvae. Even with the $20 \%$ to $50 \%$ increase in refuge, the resistance evolution is faster when the larvae are in an indiscriminate larval movement scenario, high genic flow and in a refuge with host plants (Heuberger et al. 2011). Besides the larval movement of $A$. argillacea among Bt and non-Bt cotton plants, the differential susceptibility among instars, may cause sublethal exposure and build-up resistance in populations of the target pest, due to survival increase of resistant heterozygous or of individuals that conduct resistance alleles (Wangila et al. 2012). It happens because the feeding behavior of Lepidoptera larvae may be modified between instars; however, the size and physical ability to consume certain diets may influence changes in the larvae's feeding behavior (Zalucki et al. 2002). Thus, the differential feeding behavior among A. argillacea instars must be emphasized in further studies.

In conclusion, we found that the feeding behavior of neonate $A$. argillacea is significantly different between $\mathrm{Bt}$ and non-Bt cotton cultivars. Based on the percentage of larvae found on the plant and in the organza bags as well as on the amount of vegetal tissue ingested by the larvae, $A$. argillacea shows stronger feeding preference for non-Bt cotton plants when compared to that for $\mathrm{Bt}$ cotton plants. However, factors such as temperature and exposure time may affect detection capacity and the abandonment of the plants by the larvae. It results in lower ingestion of vegetal tissue. Information about the feeding behavior and the hosting acceptance of $A$. argillacea on Bt cotton plants are relevant for the handling of its resistance to $\mathrm{Bt}$ cotton cultivars. It allows determining how the cotton seeds mix may be a feasible handling option to hold back the resistance evolution of $A$. argillacea populations to $\mathrm{Bt}$ cotton cultivars when it is compared with other refuge strategies. The results can also be useful to determine the most effective plants' refuge distribution to manage the resistance of $\mathrm{Bt}$ cotton to A. argillacea.

\section{ACKNOWLEDGMENTS}

The authors would like to thank the Conselho Nacional de Desenvolvimento Científico e Tecnológico $(\mathrm{CNPq})$ for the scholarships granted to the first author, and also thank Embrapa Algodão for their technical support.

\section{REFERENCES}

ADAMCZYK JJ AND SUMERFORD DV. 2001. Potential factors impacting season-long expression of Cry1 Ac in 13 commercial varieties of Bollgard cotton. J Insect Sci 1: 13.

AGI AL, MAHAFFEY JS, BRANDELEY JR AND VAN DUYN JW. 2001. Efficacy of seed mixes of transgenic Bt and nontransgenic cotton against bollworm, Helicoverpa zea Boddie. J Cotton Sci 5: 74-80.

BECK SD AND SCHOONHOVEN LM. 1980. Insect behavior and plant resistance. In: Maxwell FG and Jennings PR (Eds), Breeding plants resistant to insects, New York: Wiley, New York, USA, p. 115-135.

BERDEGUÉ M, TRUMBLE JT AND MOAR WJ. 1996. Effect of Cry1c from Bacillus thuringiensis on larval behavior of Spodoptera exigua. Entomol Exp Appl 80: 389-401.

BERGER A. 1992. Larval movements of Chilo partellus (Lepidoptera: Pyralidae) within and between plants: 
timing, density responses and survival. Bull Entomol Res 82: $441-448$.

BOIÇA JUNIOR AL, JESUS FG, JANINI JC, SILVA AG AND ALVES GCS. 2012. Resistência de variedades de algodão ao curuquerê do algodoeiro Alabama argillacea (Hubner) (Lepidoptera: Noctuidae). Rev Ceres 59: 48-55.

CASEY TM, JOOS B, FITZGERALD TD AND YOUNG PA. 1988. Synchronized group foraging, thermoregulation, and growth of eastern tent caterpillars in relation to microclimate. Physiol Zool 61: 372-377.

CHEN FJ, WU G, GE F, PARAJULEE MN AND SHRESTHA RB. 2005. Effects of elevated $\mathrm{CO} 2$ and transgenic $\mathrm{Bt}$ cotton on plant chemistry, performance, and feeding of an insect herbivore, the cotton bollworm. Entomol Exp Appl 115: 341-350.

CHEN Y, WEN Y, ZHANG XAND CHEN D. 2012. The effects of the relative humidity on the insecticidal expression level of Bt cotton during bolling period under high temperature. Field Crop Res 137: 141-147.

COHEN RW, HEYDON SL, WALDBAUER GP AND FRIEDMAN S. 1987. Nutrient self-selection by the omnivorous cockroach Supella longigalpa. J Insect Physiol 33: 77-82.

CUI JJ AND XIA JY. 1999. Effects of transgenic Bt cotton on the population dynamic of natural enemies. Acta Gossypii Sinica 11: 84-91.

DHURUA S AND GUJAR G. 2011. Field-evolved resistance to Bt toxin CrylAc in the pink bollworm, Pectinophora gossypiella (Saunders) (Lepidoptera: Gelechiidae), from India. P Manag Sci 67: 898-903.

DONG HZ AND LI WJ. 2007. Variability of endotoxin expression in Bt transgenic cotton. J Agron Crop Sci 193: 21-29.

EVERT RF. 2006. Esau's plant anatomy. Meristems, cells, and tissues of the plant body: their structure, function, and development. New York: Wiley, New York, USA.

GASSMANN A, PETZOLD-MAXWELL JL, KEWESHAN RS AND DUNBAR MW. 2011. Field-evolved resistance to Bt maize by Western corn rootworm. PLoS ONE 6: e22629.

GLAUM PR, IVES AR AND ANDOW DA. 2012. Contamination and management of resistance evolution to high-do se transgenic insecticidal crops. Theor Ecol 5: 195-209.

GOLDSTEIN JA, MASON CE AND PESEK J. 2010. Dispersal and movement behavior of neonate European corn borer (Lepidoptera: Crambidae) on non-Bt and transgenic Bt corn. J Econ Entomol 103: 331-339.

GORE J, ADAMCZYK JJ AND BLANCO CA. 2005. Selective feeding of tobacco budworm and bollworm (Lepidoptera: Noctuidae) on meridic diet with different concentrations of Bacillus thuringiensis proteins. J Econ Entomol 98: 88-94.
GORE J, LEONARD BR, CHURCH GE AND COOK DR. 2002. Behavior of bollworm (Lepidoptera: Noctuidae) larvae on genetically engineered cotton. J Econ Entomol 95: 763-769.

GOULD F. 1984. Role of behavior in the evolution of insect adaption to insecticides and resistant host plant. Bull Entomol Soc Am 30: 34-41.

GOULD F. 2000. Testing Bt refuge strategies in the field. Nat Biotechnol 18: 266-276.

GOULD F AND ANDERSON A. 1991. Effect of Bacillus thuringiensis and HD-73 delta endotoxin on growth, behavior, and fitness of susceptible and toxin-adapted strains of Heliothis virescens (Lepidoptera: Noctuidae). Environ Entomol 20: 30-38.

HALCOMB JL, BENEDICT JH, COOK B, RIN DR AND CORREA JC. 2000. Feeding behavior of bollworm and tobacco budworm (Lepidoptera: Noctuidae) larvae in mixed stands of nontransgenic and transgenic cotton expressing an insecticidal protein. J Econ Entomol 93: 1300-1307.

HEUBERGER S, CROWDER DW, BRÉVAULT T, TABASHNIK BE AND CARRIÈRE Y. 2011. Modeling the effects of plant-to-plant gene flow, larval behavior, and refuge size on pest resistance to Bt cotton. Environ Entomol 40: 484-495.

JOHANSEN DA. 1940. Plant microtechnique. New York: McGraw-Hill, New York, USA.

JYOTI JL, YOUNG SY, JOHNSON DT AND MCNEW RW. 1996. Helicoverpa zea (Lepidoptera: Noctuidae): larval location, mortality, and leaf area consumption on Bacillus thuringiensis treated cotton. Environ Entomol 25: 14381443.

JYOTI JL, YOUNG SY, LÓPEZ C, HERNANDEZESCAREÑO G, EIZAGUIRRE M AND ALBAJES R. 2013. Antixenosis and larval and adult dispersal in the Mediterranean corn borer, Sesamia nonagrioides, in relation to Bt maize. Entomol Exp Appl 149: 256-264.

KLUMPER W AND QAIM M. 2014. A meta-analysis of the impacts of genetically modified crops. PLoS ONE 9: e111629.

LÓPEZ C, HERNANDEZ-ESCAREÑO G, EIZAGUIRRE M AND ALBAJES R. 2013. Antixenosis and larval and adult dispersal in the Mediterranean corn borer, Sesamia nonagrioides, in relation to Bt maize. Entomol Exp Appl 149: 256-264.

MAHON R, FINERGAN J, OLSEN K AND LAWRENCE L. 2002. Environmental stress and the efficacy of Bt cotton. Aust Cotton Grow 22: 18-21.

MALLET J AND PORTER P. 1992. Preventing insect adaptation to insect-resistant crops: are seed mixes or refuge the best strategy? P R Soc Lond B 250: 165-169

MEDEIROS RS, RAMALHO FS, ZANUNCIO JC AND SERRÃO JE. 2003. Estimate Alabama argillacea 
(Hubner) (Lelidoptera: Noctuidae) development with nonlinear models. Braz J Biol 63: 589-597.

MEN X, GE F, YARDIM EN AND PARAJULEE M. 2005. Behavioral response of Helicoverpa armigera (Noctuidae: Lepidoptera) to cotton with and without expression of the Cry1Ac d-endotoxin protein of Bacillus thuringiensis Berliner. J Insect Beh 18: 33-50.

ONSTAD DW ET AL. 2011. Seeds of change: corn seed mixtures for resistance management and IPM. J Econ Entomol 104: 343-352.

PARKER CD AND LUTTRELL RG. 1999. Interplant movement of Heliothis virescens (Lepidoptera: Noctuidae) larvae in pure and mixed planting of cotton with and without expression of the Cry1Ac $\delta$-endotoxin protein from Bacillus thuringiensis Berliner. J Econ Entomol 92: 837-845.

RAMALHO FS, PACHU JKS, LIRAACS, MALAQUIAS JB, ZANUNCIO JC AND FERNANDES FS. 2014. Feeding and dispersal behavior of the cotton leafworm, Alabama argillacea (Hübner) (Lepidoptera: Noctuidae), on Bt and non-Bt cotton: implications for evolution and resistance management. PLoS ONE 9: e111588.

RAZZE JM AND MASON CE. 2012. Dispersal behavior of neonate European corn borer (Lepidoptera: Crambidae) on Bt corn. J Econ Entomol 105: 1214-1223.

RAZZE JM, MASON CE AND PIZZOLATO TD. 2011. Feeding behavior of neonate Ostrinia nubilalis (Lepidoptera: Crambidae) on Cry1 Ab Bt corn: implications for resistance management. J Econ Entomol 104: 806-813.

ROSS SE AND OSTLIE KR. 1990. Dispersal and survival of early instars of European corn borer (Lepidoptera: Pyralidae) on field corn. J Econ Entomol 83: 831-836.

SAS INSTITUTE. 2006. Sas/stat user's guide. Cary: SAS Institute, Cary, NC, USA.

SAXENA KN AND ONYANGO JD. 1990. Role of behaviour of the stem-borer Chilo partellus (Swinhoe) in determining resistance or susceptibility of certain sorghum cultivars. Symp Biol 39: 135-143.

SCHNEPF EN, CRICKMORE N, RIE JV, LERECLUR D, BAUM J, FEITELSON J AND VEGA OFL. 1999. A review of Bacillus thuringiensis $(\mathrm{Bt})$ production and use in Cuba. Biocontrol N Informa 20: 47-48.

SHEN P, LIN K, ZHANG Y, WU K AND GUO Y. 2010. Seasonal expression of Bacillus thuringiensis insecticidal protein and the control to cotton bollworm in different varieties of transgenic cotton. Cotton Sci 22: 393-397.

STAPEL JO, WATERS DJ, RUBERSON JR AND LEWIS WJ. 1998. Development and behavior of Spodoptera exigua (Lepidoptera: Noctuidae) larvae in choice tests with food substrates containing toxins of Bacillus thuringiensis. Biol Control 11: 29-37.

STORER NP, BABCOK JM, SCHLENZ M, MEADE T, THOMPSON GD, BING JW AND HUCKABA RM. 2010. Discovery and characterization of field resistance to Bt maize: Spodoptera frugiperda (Lepidoptera: Noctuidae) in Puerto Rico. J Econ Entomol 103: 1031-1038.

THU CUC NT, SUJII ER, WILSON LJ, UNDERWOOD E, ANDOW DA, HAO MV, ZHAI B AND CHIEN HV. 2008. Potential effect of transgenic cotton on non-target herbivores in Vietnan. In: Andow DA, Hilbeck A and Tua NV (Eds), Challenges and opportunities with Bt cotton in Vietnan. Wallingford: CABI Publishing, Wallingford, UK, p. 138-175.

VACHON V, LAPRADE R AND SCHWATZ JL. 2012. Current models of the mode of action of Bacillus thuringiensis insecticidal crystal proteins: a critical review. J Invertebr Pathol 11: 1-12.

XING CHZH, JING SHR, CUI XF, GUO LP, WANG HL AND YUAN YL. 2001. The spatio-temporal distribution of Bt (Bacillus thuringiensis) insecticidal protein and the effect of transgenic Bt cotton on bollworm resistance. Cotton Sci 13: $11-15$.

WANGILA DS, LEONARD BR, BAI Y, HEAD GP AND HUANG F. 2012. Larval survival and plant injury of Cry1 Ab-susceptible, -resistant, and -heterozygous genotypes of the sugarcane borer on transgenic corn containing single or pyramided Bt genes. Crop Protection 42: 108-115.

ZALUCKI MP, CLARKE AR AND MALCOL SB. 2002. Ecology and behavior of first instar larval Lepidoptera. Annu Rev Entomol 47: 361-393.

ZANCANARO PO, BUCHWEITZ ED, BOIÇA JUNIOR AL AND MORO JR. 2012. Avaliação de tecnologias de refúgio no cultivo de milho transgênico. Pesqui Agropecu Bras 47: 886-891.

ZHANG JH, WANG CZ, QIN JD AND GOU SD. 2004. Feeding behavior of Helicoverpa armigera larvae on insect-resistant transgenic cotton and non-transgenic cotton. J Appl Entomol 128: 218-225. 